\title{
Case Report Spindle Cell Lipoma of the Soft Palate
}

\author{
Ahmet Hançer, ${ }^{1}$ Can Özbay, ${ }^{2}$ Serap Karaarslan, ${ }^{3}$ and Muzaffer Balaban ${ }^{1}$ \\ ${ }^{1}$ Department of Otolaryngology, Sifa University, Bornova, 35100 İzmir, Turkey \\ ${ }^{2}$ Department of Otolaryngology, Adnan Menderes University, Aytepe Mevkii, 09100 Aydin, Turkey \\ ${ }^{3}$ Department of Pathology, Şifa University, Bornova, 35100 İzmir, Turkey
}

Correspondence should be addressed to Can Özbay; canozbay30@gmail.com

Received 16 December 2014; Revised 9 March 2015; Accepted 12 March 2015

Academic Editor: Wolfgang Issing

Copyright (c) 2015 Ahmet Hançer et al. This is an open access article distributed under the Creative Commons Attribution License, which permits unrestricted use, distribution, and reproduction in any medium, provided the original work is properly cited.

Intraoral spindle cell lipomas (SCL) are very rare and comprise ranging between $1.4 \%-9.8 \%$ of all intraoral lipomas. To our knowledge, no case of a SCL located on the soft palate has been reported in the English-language literature. A 31-year-old female was admitted with a swelling in her soft palate. On examination, a $3 \mathrm{~cm}$ sessile, nontender swelling was observed on her soft palate. After surgical excision, it was diagnosed as a SCL.

\section{Introduction}

Lipomas are benign tumours or idiopathic proliferation of adipocytes that may contain other mesenchymal tissues and mature adipose tissue arranged in lobules and separated by septa formed of fibrous connective tissue. Clinically, these tumours manifest as asymptomatic, slow-growing submucosal nodules $[1,2]$. Approximately $13 \%$ of lipomas occur in the head and neck, but oral cavity is unusual site [3]. Oral lipomas account for 2.2 to $4.4 \%$ of all benign intraoral tumours with most lesions occurring in the buccal mucosa $[3,4]$. The lipomas encountered most commonly are fibrolipomas, osteolipomas, chondrolipomas, angiolipomas, angiomyolipomas, myelolipomas, spindle cell lipomas (SCLs), pleomorphic lipomas, and sialolipomas. SCLs are composed of bland mitotically inactive spindle cells arranged in parallel with the fat cells and associated with thick rope-like collagen bundles [5]. The aetiology and pathogenesis of lipomas remain unclear [6]. Most patients are aged 40 years or older and the tumours are extremely rare in children $[6,7]$. In their series of 41 oral cavity lipomas, Juliasse et al. found four (9.8\%) SCLs, none of which were located in the soft palate [8]. We present the first case of a SCL located in the soft palate.

\section{Case Report}

A 31-year-old female was admitted with a swelling in her soft palate. On examination, an approximately $3 \mathrm{~cm}$ sessile, nontender swelling with normal mucosa and smooth surface was observed on her soft palate. Magnetic resonance imaging (MRI) revealed a $26.5 \times 22.5 \times 8 \mathrm{~mm}$ lump near the right tonsillar palate, which retained contrast substance at its surface and appeared to contain iso- to hypointense fibrils in T1 images and hypointense fibrils in T2 images (Figures 1 and 2).

Based on the initial findings, we thought that this mass might be a cyst of the minor salivary glands, fibroepithelial polyp, benign nerve sheath tumour, or nasopharyngeal tumour. After surgical excision, the specimen was sent to the pathology department. Grossly, the greatest diameter of the mass was $29 \mathrm{~mm}$. The tumour was clearly separated from the surrounding tissues. There was minor salivary gland tissue near the mass.

Histologically, the mass contained adipocytes and spindle cells and had centres with myxoid character and fine ropelike collagen between these centres (Figures 3 and 4). All immunohistochemical (IHC) staining procedures, including deparaffinisation and antigen retrieval, were performed using the Dako LV-1 Automated Immunostaining System (Dako, Denmark). The mass was strongly positive for CD34 (IR632, FLEX ready to use, Dako, Denmark) (Figure 5) with focal areas that were weakly positive for S-100.

Based on the morphological and IHC findings, the mass was interpreted as a SCL. 


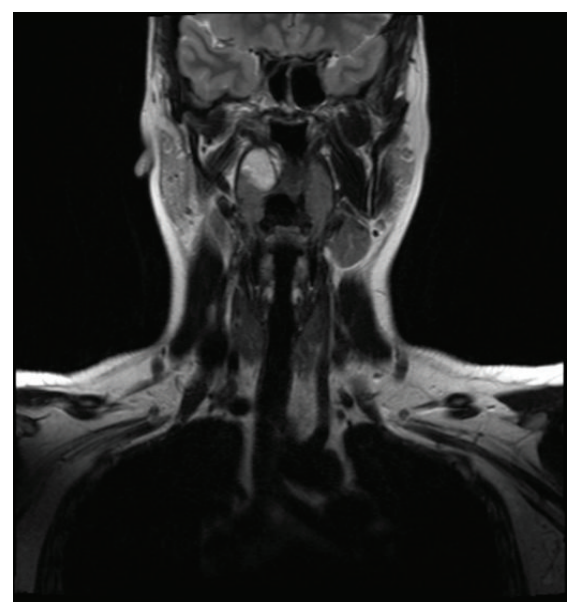

FIGURE 1: MRI shows a mass in the patient's soft palate.

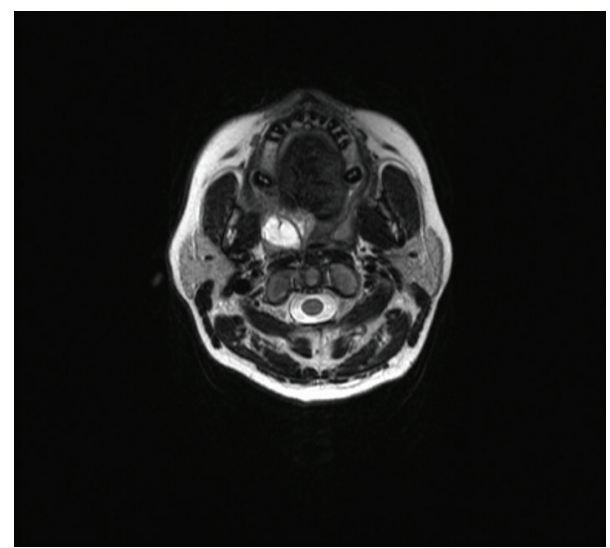

FIGURE 2: Axial MRI section of the spindle cell lipoma.

\section{Discussion}

Lipomas are benign tumours that develop via the proliferation of adipocytes [9]. There are various theories of the origin of lipomas, including heredity, a hormonal aetiology, infection, metaphase of muscle cells, the presence of lipoblastic embryonic cells, and chronic irritation [10]. Some reports suggest that $13 \mathrm{q}$ locus deletions and altered $8 \mathrm{q} 11-$ 13 cause lipomas [11]. Lipomas of the oral cavity are rare and comprise $0.5 \%$ of all oral cavity tumours [2]. Lipomas of the oral cavity form a slow-growing mass with a smooth surface [10]. SCLs were first described in 1975 by Enzinger and Harvey [12]. One subtype of SCL that typically presents as a benign lipomatous neoplasm in the posterior neck and back of older males accounts for approximately $1.5 \%$ of all lipoma cases [13]. SCLs account for 1.4-9.8\% of all intraoral lipomas $[2,8,14]$. Our review of the literature revealed that the tongue and buccal mucosa were the most common sites of intraoral SCLs, which are typically found in males aged 40-70 years. Chandrashekar et al. [10] reported a case and review of the literature that included 26 cases of SCL in 16 males and 10 females between the ages of 29 and 71 years (mean age, 56.5 years). Christopoulos et al. [15] reported first case of

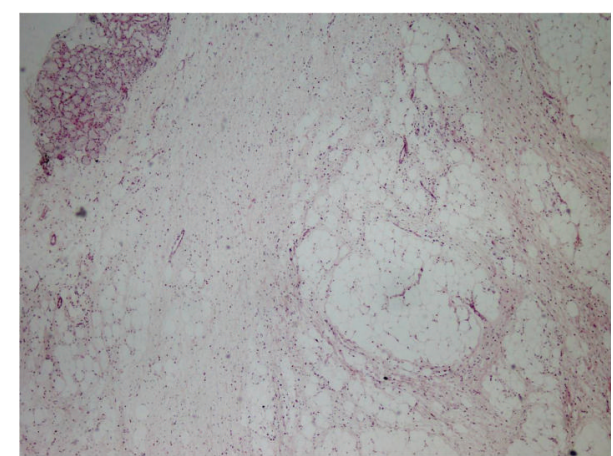

FIgURE 3: The lesion contained myxoid centres, collagen bands, adipocytes, and spindle cells with a nearby minor salivary gland $(\mathrm{H} \& \mathrm{E} \times 100)$.

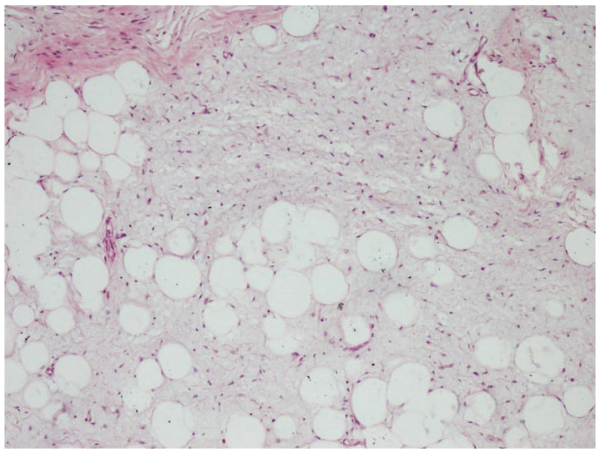

FIGURE 4: A close-up view of a myxoid area containing adipocytes and spindle cells $(\mathrm{H} \& \mathrm{E} \times 200)$.

SCL located on the hard palate adjacent to the location of the lesion in our case.

Moreover, a review of the clinicopathological features of 35 cases of oral SCL conducted by Manor et al. [16] (two of their cases and 33 from literature) revealed a male: female ratio of 1.92 (23 males and 12 females) in patients between the ages of 23 and 88 years (mean age, 55.0 years). The painless lesions were located on the tongue $(n=13)$, cheek/buccal mucosa $(n=11)$, floor of mouth $(n=5)$, lip $(n=2)$, hard palate $(n=2)$, alveolar ridge $(n=1)$, and maxilla $(n=1)$. Our review of the literature revealed 11 additional cases to those reported by Manor et al. (10 on the tongue and 1 at the mandibular mucogingival junction) [17-20].

The treatment of SCL is surgical removal. After surgery recurrence can occur. Fletcher and Martin-Bates observed one recurrence out of 41 tumours [13].

SCL are rare and the different histological patterns of these lesions might cause diagnostic difficulty. They can be confused with well-differentiated liposarcoma and myxoid liposarcoma. They are differentiated by local myxoid areas that contain CD34-positive spindle cells [13]. Liposarcomas are diagnosed easily by the presence of equal-sized lipocytes separated by fibrous septa and fibrous lipoblasts with hyperchromatic notched nuclei near the fibrous septa. Myxoid liposarcomas show distinct oedema, vessel arborisation, and 


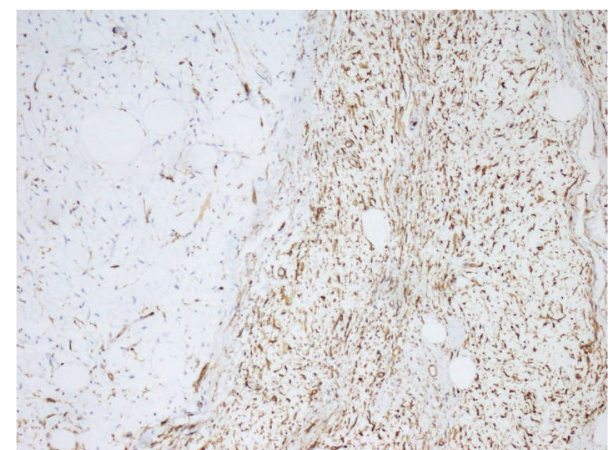

Figure 5: CD34-positive spindle cells $(\mathrm{H} \& \mathrm{E} \times 200)$.

lipoblasts at the periphery [13]. Angiolipomas and fibrolipomas contain spindle cells and can be confused with SCL. However, angiolipomas are distinguished by vessels at the tumour periphery and fibrolipomas contain dense fibrous tissue bands $[9,13]$.

Some authors have postulated that spindle cells stem from fibroblasts or are similar to the stellate mesenchymal cells of primitive fat lobules [12, 21, 22]. Others have stated that spindle cells are actually immature mesenchymal cells that remain in position during the transformation to mature lipocytes and are capable of synthesising only collagen at an early stage [13].

As no SCL has been reported in the soft palate in the English-language literature, we decided to share our findings. Although rare, this lesion must be considered when masses are identified at this location.

\section{Conflict of Interests}

The authors declare that there is no conflict of interests regarding the publication of this paper.

\section{References}

[1] M. C. Bandéca, J. M. de Pádua, M. R. Nadalin, J. E. V. Ozório, Y. T. C. Silva-Sousa, and D. E. D. C. Perez, "Oral soft tissue lipomas: a case series," Journal of the Canadian Dental Association, vol. 73, no. 5, pp. 431-434, 2007.

[2] E. R. Fregnani, F. R. Pires, R. Falzoni, M. A. Lopes, and P. A. Vargas, "Lipomas of the oral cavity: clinical findings, histological classification and proliferative activity of 46 cases," International Journal of Oral and Maxillofacial Surgery, vol. 32, no. 1, pp. 49-53, 2003.

[3] L. Barnes, "Tumours and tumour-like lesions of the soft tissues," in Surgical Pathology of the Head and Neck, L. Barnes, Ed., pp. 725-880, Marcel Dekker, New York, NY, USA, 1985.

[4] G. W. Wilson, T. W. Braun, and R. L. Smith, "Nodular mass in the anterior floor of the mouth," Journal of Oral and Maxillofacial Surgery, vol. 48, no. 5, pp. 492-495, 1990.

[5] M. M. Miettinen and N. Mandalh, "Spindle cell lipoma/ pleomorphic lipoma," in Pathology and Genetics of Tumours of Soft Tissue and Bone, C. D. Flethcer, K. Unni, and F. Mertens, Eds., WHO Classification of Tumours, pp. 31-32, IARC Press, Lyon, France, 2002.
[6] B. W. Neville, D. D. Damm, C. M. Allen, and J. E. Bouquot, "Soft tissue tumors," in Oral and Maxillofacial Pathlogy, B. W. Neville, D. D. Damm, C. M. Allen, and J. E. Bouquot, Eds., pp. 452-454, WB Saunders Company, Philadelphia, Pa, USA, 2002.

[7] M. Venkateswarlu, P. Geetha, and M. Srikanth, "A rare case of intraoral lipoma in a six yearold child: a case report," International Journal of Oral Science, vol. 3, no. 1, pp. 43-46, 2011.

[8] L. E. R. Juliasse, C. F. W. Nonaka, L. P. Pinto, R. D. A. Freitas, and M. C. D. C. Miguel, "Lipomas of the oral cavity: clinical and histopathologic study of 41 cases in a Brazilian population," European Archives of Oto-Rhino-Laryngology, vol. 267, no. 3, pp. 459-465, 2010.

[9] T. Lombardi and E. W. Odell, "Spindle cell lipoma of the oral cavity: report of a case," Journal of Oral Pathology \& Medicine, vol. 23, no. 5, pp. 237-239, 1994.

[10] P. Chandrashekar, M. Jose, M. Dadhich, L. Chatra, and V. Holla, "Spindle cell lipoma: a case report and review of literature," Kathmandu University Medical Journal, vol. 10, no. 38, pp. 9295, 2012.

[11] G. Colella, P. Biondi, R. Caltabiano, G. M. Vecchio, P. Amico, and G. Magro, "Giant intramuscular lipoma of the tongue: a case report and literature review," Cases Journal, vol. 2, article 7906, 2009.

[12] F. M. Enzinger and D. A. Harvey, "Spindle cell lipoma," Cancer, vol. 36, no. 5, pp. 1852-1859, 1975.

[13] C. D. M. Fletcher and E. Martin-Bates, "Spindle cell lipoma: a clinicopathological study with some original observations," Histopathology, vol. 11, no. 8, pp. 803-817, 1987.

[14] N. Said-Al-Naief, F. R. Zahurullah, and J. J. Sciubba, "Oral spindle cell lipoma," Annals of Diagnostic Pathology, vol. 5, no. 4, pp. 207-215, 2001.

[15] P. Christopoulos, O. Nicolatou, and A. Patrikiou, "Oral spindle cell lipoma. Report of a case," International Journal of Oral \& Maxillofacial Surgery, vol. 18, no. 4, pp. 208-209, 1989.

[16] E. Manor, N. S. Vardy, P. A. Brennan, and L. Bodner, "Spindle cell lipoma of the oral cavity: a clinico-pathologic analysis of 35 reported cases," Surgical Science, vol. 4, no. 3, pp. 196-201, 2013.

[17] O. C. Júnior, E. C. G. de Aguiar, J. H. F. Sartori, and F. de Oliveira Lima, "Spindle cell lipoma of the tongue: a case report of unusual occurrence," Journal of Oral \& Maxillofacial Pathology, vol. 17, no. 1, p. 148, 2013.

[18] S. K. Lau, J. A. Bishop, and L. D. Thompson, "Spindle cell lipoma of the tongue: a clinicopathologic study of 8 cases and review of the literature," Head and Neck Pathology, 2014.

[19] M. A. Al Sheddi, A. Assari, and H. Mosadomi, "Spindle cell lipoma of the mandibular mucogingival junction: a case report of unusual oral neoplasm," International Journal of Oral Science, vol. 6, no. 3, pp. 185-187, 2014.

[20] H. P. Lin, C. J. Liu, and C. P. Chiang, "Spindle cell lipoma of the tongue," Journal of the Formosan Medical Association, 2015.

[21] R. K. McDaniel, J. R. Newland, and D. G. Chiles, "Intraoral spindle cell lipoma: case report with correlated light and electron microscopy," Oral Surgery, Oral Medicine, Oral Pathology, Oral Radiology, vol. 57, no. 1, pp. 52-57, 1984.

[22] L. Angervall, I. Dahl, L. G. Kindblom, and J. Save-Söderbergh, "Spindle cell lipoma," Acta Pathologica et Microbiologica Scandinavica Section A: Pathology, vol. 84, no. 6, pp. 477-487, 1976. 


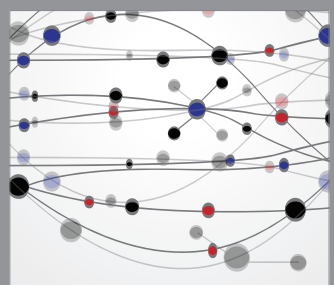

The Scientific World Journal
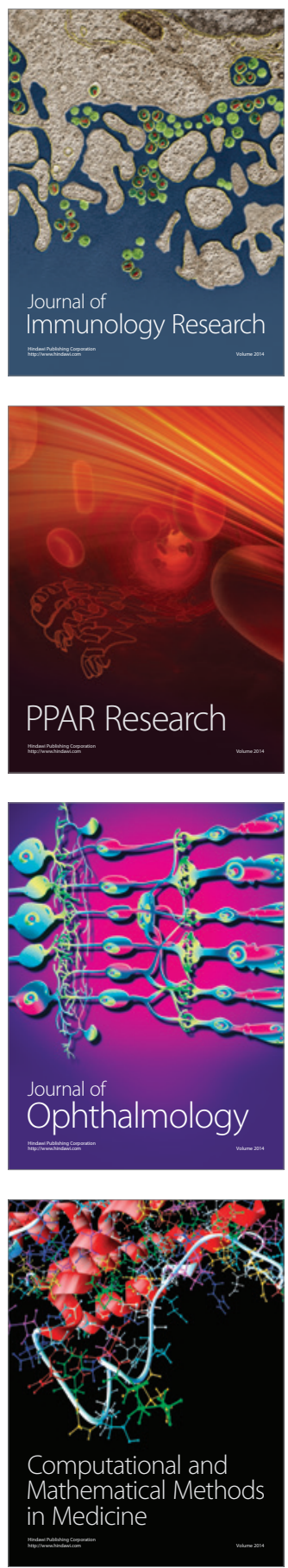

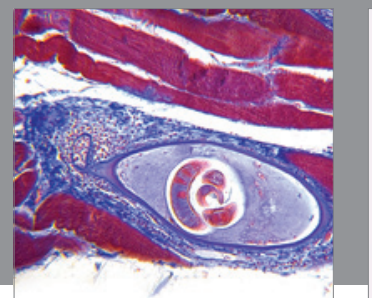

Gastroenterology

Research and Practice
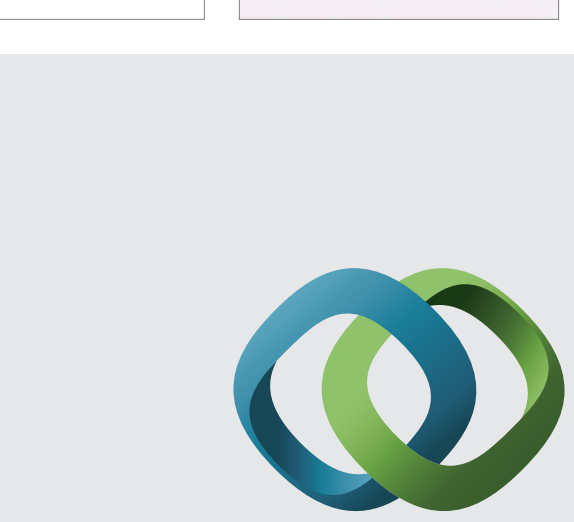

\section{Hindawi}

Submit your manuscripts at

http://www.hindawi.com
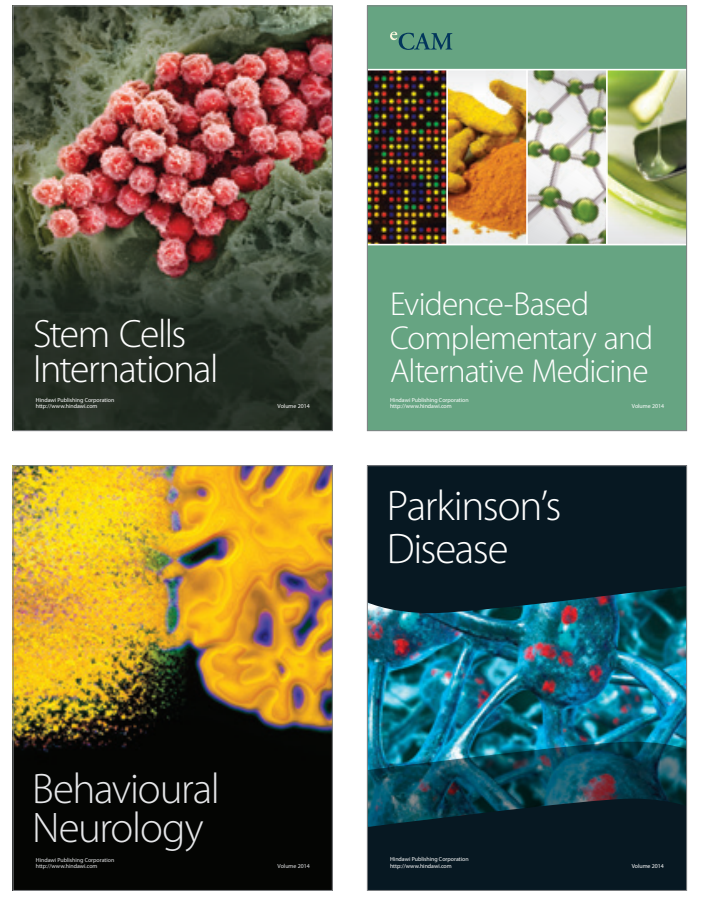
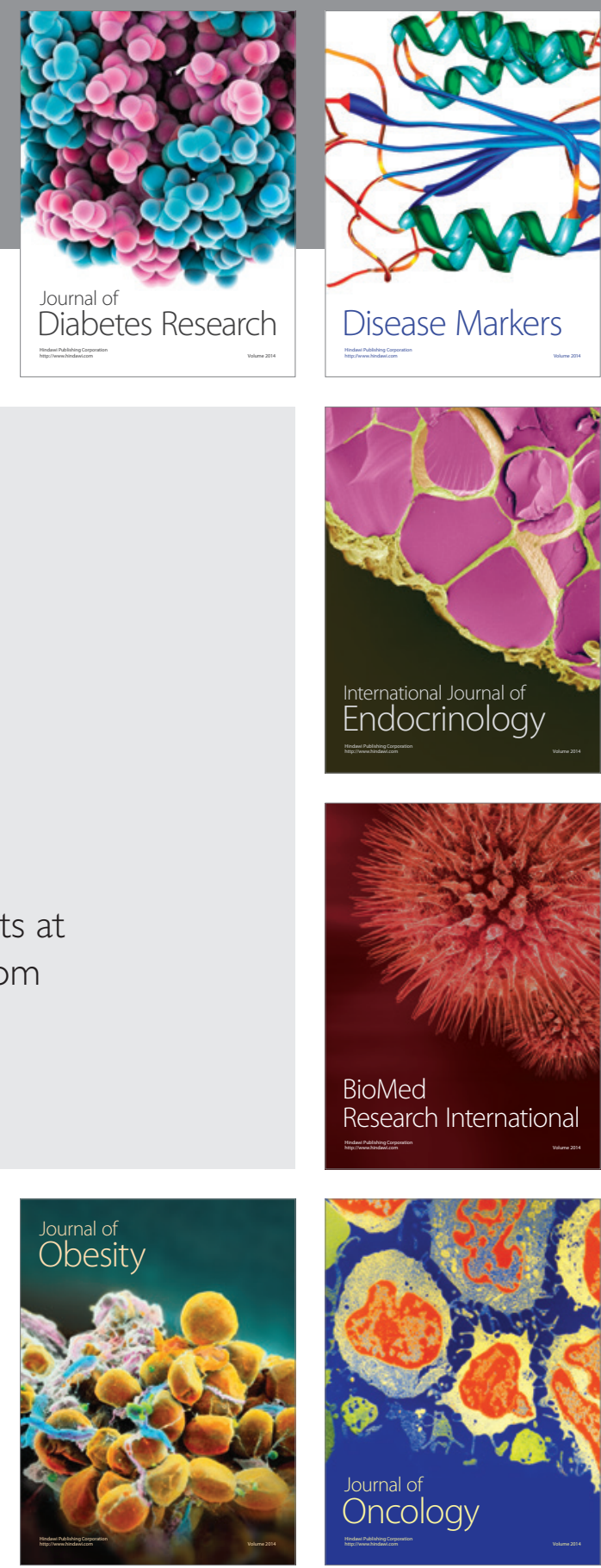

Disease Markers
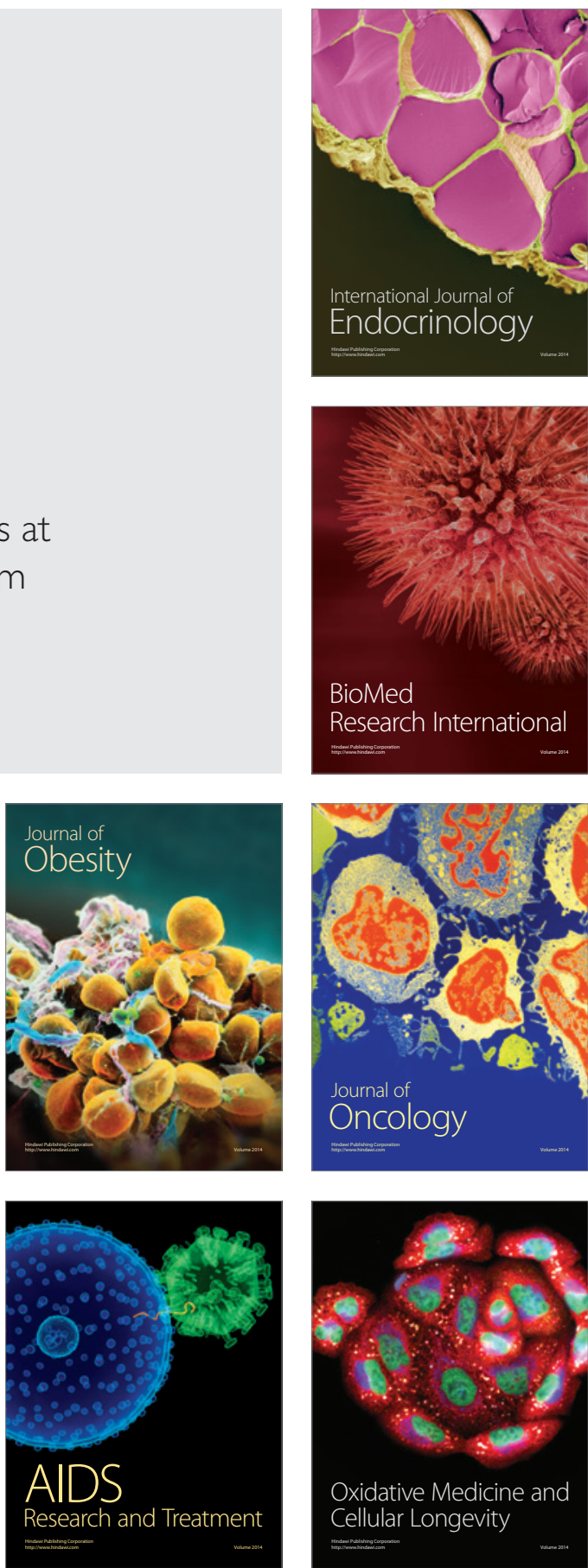